\title{
LEITURAS GEOGRÁFICAS EM OLIVEIRA VIANNA ${ }^{1}$
}

Resumo: O objetivo desse texto é analisar as discussões do pensador brasileiro Oliveira Vianna (1883-1951) sobre raça e meio na sociedade brasileira. Busca-se compreender como esse autor tenta equacionar os dois problemas que envolviam a formação de uma nação brasileira "desenvolvida" e "civilizada" no início do séc. XX: a população composta majoritariamente por "raça inferior" e as determinações impostas pelo meio tropical tórrido e degenerador. Oliveira Vianna enxergava na resolução dos problemas da raça e do meio tropical a única saída viável para o país. Acreditando na superioridade "ariana", o autor enfatiza a necessidade de inserir no território brasileiro população proveniente da Europa. É nesses termos que o autor produz um discurso geográfico, pois, estabelece discussões sobre a relação homem-meio e apresenta uma proposta de planejamento regional para a "alocação racional" dos "tipos arianos" para os meios naturais adequandos a sua racialidade. É importante compreender o discurso geográfico de Oliveira Vianna pois, ele influenciou uma série de geógrafos que buscaram analisar as diferenças regionais e o povo brasileiro.

Palavras-chave: Oliveira Vianna. Meio. Raça. Discurso geográfico. Nação.

\section{GEOGRAPHICAL INTERPRETATIONS IN OLIVERIA VIANNA}

Abstract: The purpose of this paper is to analyze the discussions of the Brazilian thinker Oliveira Vianna (1883-1951) about race and environment in the Brazilian society. It seeks to understand how the author tries to equate the two problems involving a formation of a "developed" and "civilized" Brazilian nation at the beginning of $20^{\text {th }}$ century: the population mostly composed by "inferior race" and the determinations imposed by the degenerating tropical environment. Participating of a series of debates on a national project for Brazil, Vianna saw in the resolution of the race and environment issues a viable way for the country. Believing in "aryan" superiority, the author emphasizes the need to insert in the Brazilian territory a population from Europe. Producing a geographical discourse, the author establishes discussions on the men-environment relationship and makes a proposal of a regional planning for the rational allocation of "aryans types" in the Brazilian natural regions. It is important to understand the Vianna's geographical discourse because he later influenced a set of geographers who sought to discuss the regional differences and the population in Brazil.

Keywords: Oliveira Vianna. Environment. Race. Geographical discourse. Nation.

\section{LECTURAS GEOGRÁFICAS EN OLIVEIRA VIANNA}

Resumen: El objetivo de esta ponencia es analizar las discusiones del pensador brasileño Oliveira Vianna (1883-1951) sobre raza y medio en la sociedad brasileña.

\footnotetext{
1 Partes desse texto foram apresentadas no IV Encontro Nacional de História do Pensamento Geográfico e II Encontro Nacional de Geografia Histórica (2016) e na Revista Geosaberes (2018).

2 Universidade Federal Fluminense, Departamento de Geografia e Políticas Públicas (DGP-IEAR), Angra dos Reis-RJ, Brasil, diogomc@id.uff.br, https://orcid.org/0000-0002-5122-7147.
} 
Se busca comprender cómo ese autor intenta resolver los dos problemas que involucra la formación de una nación brasileña "desarrollada" y "civilizada" al inicio del siglo XX: la población compuesta mayoritariamente por "raza inferior" y las determinaciones impuestas por el medio tropical tórrido y que degenera. Siguiendo una serie de debates sobre un proyecto de nación para Brasil, Vianna veía en la resolución de los problemas de la raza y del medio la única salida viable para el país. Creyendo en la superioridad "ario", el autor enfatiza la necesidad de insertar en el territorio brasileño población proveniente de Europa. El autor establece discusiones sobre la relación hombre-medio y presenta una propuesta de planificación regional para la "asignación racional" de los "tipos ario" en los diversos medios naturales brasileños. Es importante comprender el discurso geográfico de Vianna porque el influyo en una serie de geógrafos posteriores que buscaron discutir la diferencia regional y el pueblo brasileño.

Palabras clave: Oliveira Vianna. Medio ambiente. Raza. Discurso geográfico. Nación.

\section{Introdução}

Somos o único grande país de imigração ariana situada em região tropical - e só este fato basta para mostrar o aspecto singular do problema entre nós.

Oliveira Vianna

O objetivo desse texto é realizar, à luz da história do pensamento geográfico (LIVINGSTONE, 1992; BERDOULAY, 2013), das discussões de Oliveira Vianna sobre o meio e a raça na sociedade brasileira. Busca-se compreender como esse autor tenta equacionar os dois "problemas" que envolviam a formação de uma nação "desenvolvida" e "civilizada"; a população composta majoritariamente por "raça inferior" (leia-se, negros, indígenas e mestiços); e, as "determinações" impostas pelos trópicos "tórridos" e "degenerantes". Seguindo uma linhagem de debates sobre um projeto de nação para o Brasil que se iniciaram pari passu com a formação da Primeira República e o pós-abolição, Vianna enxergava na resolução dos problemas da raça e do meio - pela "ciência moderna" - uma das saídas viáveis para o país.

Como demonstra a historiografia desse período, há uma gama bastante ampla de autores que debateram e estiveram envolvidos com os dilemas relativos a raça, o meio e a nação (MURARI, 2009). Nesse sentido, dois aspectos influenciaram para que fosse destacado para as análises que seguem Oliveira Vianna. Primeiramente, as obras desse autor figuram entre as mais importantes e influentes na interpretação sobre a sociedade brasileira, obras que "fixaram (...) questões que 
continuam a nos atormentar" (RICUPERO, 2011, 45-46). Sendo assim, é figura central no pensamento social brasileiro e está presente tanto na bibliografia que busca analisar as relações raciais brasileiras (cf. GUIMARÃES, 2004; SHCWARCZ, 1999; SKIDMORE, 1976), quanto na bibliografia geográfica que buscou debater a diversidade regional e populacional brasileira (cf. MACHADO, 1995, 2000). Ainda assim, poucos foram os comentadores que notaram ou deram importância às articulações entre raça e meio em Vianna. Produzindo leituras que não dialogam entre si, alguns autores enfatizaram as relações raciais e outros deram ênfase ao meio e/ou ao território, mesmo que o autor não tenha separado em suas interpretações as questões raciais (ou sociais) das relações que envolvem o meio.

Do mesmo modo, compreendê-lo é importante para entendermos o próprio pensamento levado a cabo na geografia brasileira, pois, a rigor, as teorizações e tematizações de Vianna, para o bem ou para mal, estão entre as que balizaram as ciências sociais no Brasil, dentre elas a Geografia, que tiveram que com ele dialogar para criar o próprio campo de reflexão. Isso pode ser notado na produção de uma série de geógrafos dos anos de 1930 aos de 1970 (CARVALHO, 1926; BACKHEUSER, 1926; AZEVEDO, 1975 [1969]; SANTOS, 1948; RODRIGUES, 1970).

O segundo motivação para tratar de Vianna, é a maneira como o mesmo manipulou teorias geográficas. De fato, ao focar em temas como meio, povo e nação, intencionalmente ou não, ele conformou teorizações geográficas. Assim, um dos pressupostos aqui é que os esforços desse autor em resolver o problema que envolvia a raça e o meio o levou a produzir um discurso geográfico, ainda que não fosse um geógrafo estrito senso ou não se identificasse diretamente com o campo. Pelo autor fica evidente, como destaca Machado (1995, 2000), como as Ciências Sociais no Brasil tiveram um fundo geográfico em sua constituição. Ademais, e talvez isso possa demonstrar o não acaso desse fato, Vianna estava a par dos debates e teorias geográficas "mais avançadas" de sua época que vinham sendo produzidas na Europa e nos Estados Unidos, nos quais, inclusive, se baseou para compor muitas de suas proposições.

Tendo em vista que a produção de Vianna é bastante ampla, além de existir no pensamento social uma gama extensa de debates e análises em torno dela, foco 
aqui em três obras: Populações Meridionais do Brasil (1920), Evolução do povo brasileiro (1923) e Raça e Assimilação (1932). Raça e Assimilação, em especial, nos é importante aqui. A despeito de ser uma obra renegada, tanto pelos que analisam o pensamento social de Oliveira Vianna (cf. RICUPERO, 2011; CARVALHO, 2000; ALVES FILHO, 2011), quanto por geógrafos que tratam do referido autor (BINSZTOK \& CAETANO, 2009), devido o teor polêmico de suas afirmações, é onde Vianna tem mais acabada e explicada suas teorias racialistas referentes a adaptação dos povos - efetivamente, das raças - ao meio tropical. Todo um conjunto de discussões e proposições teóricas sobre meio, raça e nação apontadas em sua primeira fase de produção, em obras bastante difundidas como Populações Meridionais do Brasil e Evolução do povo brasileiro, foram ampliadas e aperfeiçoadas nesse livro de 1932 .

Por fim, deve-se destacar que a mestiçagem e a assimilação da "população ariana" parecem ser os grandes problemas teóricos de Vianna. O autor se debruça sobre esses temas tendo como pano de fundo o desejo de branqueamento da população brasileira, o que era compreendido por ele como sinônimo de desenvolvimento. Assim, uma questão racialista atravessou a sua produção: como assimilar ao "meio tropical degenerador" uma "população ariana superior" para nos propiciar o "desenvolvimento civilizacional"?

O artigo está organizado na seguinte ordem: primeiramente são apresentados aspectos da vida e da obra de Oliveira Vianna; em seguida, as perspectivas sobre meio, raça e mestiçagem no método do autor; os problemas referentes a raça na formação nacional no Brasil; e é discutido a proposta metodológica do autor para planificação da alocação regional de população ariana no território brasileiro; ao fim, são realizadas as considerações finais.

\section{Referências (Geográficas) para se pensar a nação e a relação raça-meio}

Oliveira Vianna é certamente um dos autores mais importantes e influentes da primeira metade do séc. XX no Brasil. O primeiro livro publicado por ele é justamente Populações Meridionais do Brasil (1920). Já com 37 anos, ele se torna quase que imediatamente uma celebridade literária por conta da repercussão dessa obra. Essa condição de sumidade, Ihe possibilitou o incentivo e as condições para a publicação, 
seguidamente, de mais cinco livros ${ }^{3}$ durante a década de 1920. Como efeito do volume e da importância de sua obra no contexto brasileiro, em 1937 Vianna foi eleito membro da Academia Brasileira de Letras (ABL).

Apesar de uma constante atualização teórica e bibliográfica, de acordo com Carvalho (2000), há um "panteão básico de referências" utilizado por Vianna nos anos de 1920, primeira fase de sua produção. Grande parte de suas referências, teorizações e análises em Raça e Assimilação (1932) já vinham sendo tratadas nos seus escritos durante a década de 1920, especialmente em Populações Meridionais do Brasil (1920) e Evolução do Povo Brasileiro (1923).

Aqui não trataremos das bases teóricas gerais de Vianna ${ }^{4}$, mas, sim, das referências que utilizou para compreender os impactos do meio tropical nos "tipos raciais" no Brasil. Muitas das referências utilizadas por ele em discussões sobre o meio físico brasileiro - o "meio cósmico" em suas palavras - e a "aclimatação" de "tipos arianos" no Brasil, provém de geógrafos estadunidenses e europeus ${ }^{5}$. Se não exatamente desses, de textos publicados em periódicos de Geografia, notadamente do Geography Review, periódico da The American Geographical Society. Deve-se ressaltar, que o autor demonstra conhecimento das distintas tendências nacionais da produção do conhecimento geográfico no período, como por exemplo: da "'antropogeografia' dos alemães, a 'geografia social' dos franceses, a 'geografia humana' dos ingleses ou aquilo que os americanos chamam, com muito maior felicidade, a 'ecologia humana"' (VIANNA, 1959[1932], p. 163) ${ }^{6}$.

Também, figuras centrais em suas discussões são Friedrich Ratzel (18441904) e Vidal de La Blache (1945-1918), entretanto, estes autores são lidos a partir

\footnotetext{
${ }_{3}$ Pequenos Estudos de Psicologia Social (1921), O Idealismo na Evolução Política do Império e da República (1922), Evolução do Povo Brasileiro (1923), O Ocaso do Império (1925), O Idealismo na Constituição (1927) e Problemas de Política Objetiva (1930).

${ }^{4}$ Para uma análise mais amplas das referências de Oliveira Vianna ver Carvalho $(1991,2000)$, Ricupero (2011) e Bresciani (2007).

${ }^{5}$ Vianna na verdade utiliza o termo "anthropogeographistas" para identificar geógrafos e a Geografia em suas discussões, talvez uma referência direta aos escritos de Ratzel, quem era uma das referências do autor para se pensar a adaptabilidade de europeus no Brasil.

${ }^{6}$ Essas considerações são realizadas quando das críticas feitas por Vianna a "sociologia regional" do "sociólogo hindú" Radhakamal Mukerjee. Segue na íntegra: "Esta denominação de "sociologia regional" [o que envolve a relação "homem e natureza"] foi sugerida a MUKERJEE por TAGORE - e será talvez essa a única originalidade do título. Porque (...) o campo explorado por MUKERJEE não é propriamente novo: a "sociologia regional" do pensador hindu não é senão a "antropogeografia" dos alemães, a "geografia social" dos franceses, a "geografia humana" dos ingleses ou aquilo que os americanos chamam, com muito maior felicidade, a "ecologia humana"." (VIANNA, 1959[1932] p. 163)
} 
da obra publicada em 1922 de Lucien Febvre, La Terre et l'évolution humaine. Nesse sentido, ainda que Vianna enxergasse em Febvre um "espírito claramente antigermânico" que, por conseguinte, o levava a "reagir contra a concepção antropogeográfica de Ratzel" (VIANNA, 1959[1932], p. 138), ele prefere o "possibilismo" de La Blache ao "determinismo" ratzeliano deduzido por Febvre. Pensando a partir da querela criada pelo historiador francês, diz ele:

Entre essas forças, que influem sobre a evolução das sociedades e concorrem para a heterogeneização da sua estrutura e da sua marcha, estão, em primeira linha, porque irredutíveis e incoercíveis, as forças oriundas do meio cósmico, principalmente o solo, que é base física das sociedades. Para Ratzel, por exemplo, ele "regula o destino dos povos com uma cega brutalidade". Certo, hoje, ninguém partilha desse fatalismo geográfico de Ratzel. Em lugar desse determinismo cego, a ciência moderna contrapõe o "possibilismo" de Vidal de La Blache, que faz do homem uma força inteligente, reagindo contra o determinismo do meio físico, e não um mero autômato, impelido cegamente por ele. Contudo, por mais que o homem faça para se libertar das influências do ambiente cósmico, delas nunca conseguirá libertar-se inteiramente. Di-lo Lucien Febvre, embora partidário decidido do "possibilismo" de La Blache. E com ele toda a ciência social contemporânea. (VIANNA, 1933[1923], p. 35-36)

Deve-se ressaltar também que suas discussões sobre o "possibilismo" não são realizadas a partir propriamente de La Blache, mas de seus discípulos; mais exatamente, de Jean Brunhes e Camille Vallaux em La geographie de I'histoire (1921). Como muito bem notou Machado (1995, p. 343) sobre essa influência: "[é] nas zonas fitogeográficas de Jean Brunhes que [Vianna] se inspira para dividir o Brasil em três grandes zonas geográficas - os sertões, as matas e os pampas. A cada um corresponde uma história diferente, o que gerou uma sociedade diferente e, por conseguinte, três tipos específicos - o sertanejo, o matuto e o gaúcho"7.

Ainda que Vianna se colocasse avesso à postura "anti-germanista" de Febvre, Ihe parecia mais coerente e tático a adoção do "possibilismo" para se

\footnotetext{
7 De forma mais detalhada, a partir desses autores, Vianna deteve-se na caracterização social do povo brasileiro de modo a ressaltar o quanto somos distintos dos outros povos, principalmente dos "grandes povos europeus", e busca postular, simultaneamente, a diversidade interna ao próprio "povo" em termos de raças diferentes, mas também em termos de regiões mesológicas distintas, seguro em sua "convicção contrária ao preconceito da uniformidade atual do nosso povo". Utilizandose das teses do determinismo do meio físico, a pressão dos meios - no que se conectam "habitats" e fatores históricos e sociais - sobre os "elementos étnicos", distinguiu no território brasileiro "três histórias diferentes: a do norte, a do centro-sul, a do extremo-sul, das quais teriam resultado três sociedades diferentes: a dos sertões, a das matas, a dos pampas, com seus três tipos específicos: 0 sertanejo, o matuto, o gaúcho". Diversidade populacional, usos e costumes diversos, submetidos, a seu ver, a uma "constituição idealista", que considerou representar o obstáculo maior à organização do Estado nacional, à unidade e à identidade do povo (BRESCIANI, 2007, p. 44-45).
} 
pensar a sociedade brasileira, pois, por um lado, isso the livrava da ideia secular de meio tropical como uma prisão degenerante intransponível e, por outro, projetava o problema da "evolução social" no "homem". Essa ideia acompanha toda a primeira fase de produção de Vianna. De alguma forma, essa perspectiva fez com que suas discussões se concentrassem no fator raça, onde se deveria intervir caso quiséssemos alcançar um patamar "respeitável" de desenvolvimento civilizacional. Uma vez que o meio não era um problema, mas um arcabouço de possibilidades, para uma "raça superior" obviamente, o autor passa a dedicar parte de suas investigações a "seleção telúrica", "aclimatação", "seleção eugênica", "assimilação", "cruzamentos", "psicologia diferencial dos tipos antropológicos" dos imigrantes assentados ou que se assentariam nas várias "zonas" naturais no Brasil (VIANNA, 1933 [1923], p. 11).

\section{RAÇA, MEIO E NAÇÃO NO MÉTODO DE OLIVEIRA VIANNA}

Dentre as questões tratadas por Oliveira Vianna, destacam-se principalmente as que gravitavam em torno da formação e desenvolvimento da nação, cujos temas capitais eram, como já mencionado, os tipos raciais, a mestiçagem, a adaptação ao meio tropical e a formação de uma nação adiantada. Em sua primeira fase de estudos, o autor se preocupou em pensar a natureza da sociedade brasileira a partir de um "método rigorosamente científico", em sua visão. A despeito de trazer uma série de novas leituras e perspectivas, seguia o caminho trilhado por alguns autores, dentre eles, seu mestre, Sílvio Romero, no que toca a racialidade e seus desdobramentos na sociedade brasileira.

Por exemplo, persistem perspectivas que enfatizavam as diferenças e hierarquizações entre as raças e a crença na influência do meio - em especial do clima tropical - sobre a subjetividade dos sujeitos ou grupos raciais. Como para muitos pensadores predecessores de Vianna, para que pudéssemos nos tornar uma nação desenvolvida e civilizada deveríamos sanar ambas as problemáticas. Apesar de ser complexa e multifacetada, uma parte considerável das teorizações de Vianna sobre nação partem desse ponto. Vejamos mais a fundo como se conformou tal leitura em suas discussões.

Primeiramente, deve-se ressaltar que nos vários trabalhos que buscou tratar 
de "nossa gente", Vianna o fez, em suas palavras, fundamentado nas mais "avançadas" pesquisas científicas da época - a partir das quais também arrogava objetividade e imparcialidade em sua metodologia. Justamente dessas bases "científicas" que, em suas leituras, havia uma forte associação entre estudos biológicos e sócio-históricos:

Estudando as nossas realidades históricas e sociais, o nosso povo, a sua estrutura, a sua psicologia, e a vida, a estrutura e a psicologia dos grupos regionais, que o compõem, faço-o com o mesmo espírito de objetividade e a mesma imparcialidade com que os técnicos do Serviço de Defesa Agrícola estão agora estudando a praga vermelha dos cafezais da Paraíba ou os sábios de Manguinhos estudaram, entre as populações do planalto e da costa, a função patogênica do necator americanus.

Como nestes, o que me inspira é o mais absoluto sentimento de objetividade: somente os fatos me preocupam e somente trabalhando sobre eles é que infiro e deduzo. Nenhuma ideia preconcebida. Nenhuma preocupação de escola. Nenhuma limitação de doutrina. Nenhum outro desejo senão o de ver as coisas como as coisas são - e dizê-las realmente como as vi. $\mathbf{O}$ meu grande, o meu principal empenho é surpreender $\mathbf{0}$ Homem, criador da história, no seu meio social e no seu meio físico, movendo-se e vivendo neles, como o peixe no seu meio líquido (VIANNA, 1933[1923], p. 57-58, grifos adicionados).

Partindo da premissa que conecta o biológico e o social, Vianna tinha uma forte crença de que a situação presente e os problemas econômicos, políticos e sociais do Brasil só seriam resolvidos se sua história fosse bem sondada, desde os primórdios da colonização ${ }^{8}$. A análise histórica dos fatos e fatores que formaram o país permitiria reconstruir as diversas fases evolutivas e desvendar o modo particular do caráter da nação, especialmente do povo brasileiro. Inclusive, era desse trabalho de pesquisa histórica que estava "dependendo o futuro e a grandeza da civilização do Ocidente - flor delicada dos climas frios - nestes climas tropicais" (VIANNA, 1933[1923], p. 46).

É com esse olhar que ele também crê na existência de um complexo

\footnotetext{
${ }^{8}$ De acordo com Bresciani $(2005,26)$, Vianna "estava convencido de que os problemas de diversas ordens, presentes nas primeiras décadas de experiência republicana, encontravam-se firmemente enraizados no começo da vida colonial. Um mal de origem a ser desvendado e devidamente purgado por uma ação política consciente. Origem essa responsável pela herança colonial lusa e pela identidade nacional imperfeitamente constituída, verdadeiros obstáculos à plena configuração do país como nação. Sua proposta de revisar a história do Brasil, na certeza de que os problemas do presente encontravam-se em vícios de origem, foi compartilhada por vários intelectuais seus contemporâneos, autores, que com ele, se propuseram a reapresentar esse percurso de quatrocentos anos. Constituem trabalhos de interpretação histórica, que embora fundamentados em campos conceituais diferentes, convergiam no tocante à crítica aos procedimentos correntes na historiografia de finais do século XIX e início do XX, alguns denominados pejorativamente de positivistas, outros de história dos eventos políticos".
} 
heterogêneo de fatores que influem para a formação e a evolução dos povos, estes "vindos da Terra, vindos do Homem, vindos da Sociedade, vindos da História", ou de maneira mais exata, "fatores étnicos, fatores econômicos, fatores geográficos, fatores históricos [e] fatores climáticos" (VIANNA, 1933[1923], p.35). Limitar-se a um único fator, ainda que alguns tivessem preponderância em determinadas formações, geraria uma visão reducionista da realidade, segundo o autor. Por isso, acreditando que "não há monocausalismos em ciências sociais" (ibdem, p. 35), dá preferência ao "heterogêneo social de que fala Gabriel Tarde (...) ao homogêneo social de Spencer" (ibdem, p.33) ${ }^{9}$.

Do mesmo modo, o autor busca romper com leis pré-estabelecidas e deterministas:

\begin{abstract}
Desde o momento em que a ciência confessava a sua ilusão e reconhecia que as leis gerais, a que havia chegado, não correspondiam à realidade das formas infinitas da vida, compreendi que a melhor coisa a fazer não era insistir por encerrar a nossa evolução nacional dentro dessas fórmulas vãs ou querer subordinar o nosso ritmo evolutivo a um suposto ritmo geral da evolução humana - ao evolucionismo spenceriano, como fez Sylvio Romero, à teoria filogenética de Haeckel, como fez Fausto Cardoso, ou à lei dos três estados, de Comte, como têm feito os positivistas sistemáticos. Pareceu-me trabalho inútil esforçar-me por descobrir nos acontecimentos da nossa história a revelação dessas leis gerais, de que a própria ciência acabava de instaurar o processo de falência. O mais sábio caminho seria tomar para ponto de partida o nosso povo e estudar-lhe a gênese e as leis da própria evolução. Se estas coincidissem com as supostas leis gerais, tanto melhor para a ciência e para nós; senão, ficaríamos, pelo menos, "conhecendo-nos a nós mesmos" - o que já seria alguma coisa, porque valeria o consolo de estarmos com a sabedoria dos antigos (VIANNA, 1933[1923], p.43).
\end{abstract}

No entanto, apesar de uma proposta teórica profícua e complexa, ao buscar abarcar as diversas "dimensões genéticas" da realidade brasileira, dentre os fatores primordiais para se compreender o Brasil são destacados: o "povo" ("massa humana", "raça" ou "etnia") e o "ambiente cósmico" ("habitat", "meio físico" ou o "clima"). Ele demonstra isso ao criticar as omissões dos "velhos historiadores":

duas coisas, realmente, não aparecem nas obras dos nossos velhos

\footnotetext{
${ }^{9} \mathrm{Em}$ trabalhos posteriores autor continuou seguindo essa lógica. Em 1949, inspirado pela "integralist sociology, de que (...) [lhe] fala Sorokin e que concebe a realidade social como um complexo multifário (a complex manifold)", ressalta que, "em suma, o quadro clássico dos fatores da Civilização e da História se está restaurando. Em vez de uma causa única - meio só (Buckle), ou raça só (Lapouge), ou cultura só (Spengler, Frobenius, Boas) - a ciência confessa que tudo se encaminha para uma explicação múltipla, eclética, conciliadora: Raça + Meio + Cultura. Com estes elementos é que ela está recompondo o quadro moderno dos fatores de Civilização" (VIANNA, 1999[1949], p.515; p. 90).
} 
historiadores senão furtivamente e a medo, duas coisas sem as quais a história se torna defectiva e parcial. A primeira é o povo, a massa humana sobre que atuam os criadores aparentes da história: vice-reis, governadores gerais, tenentes-generais, funcionários de graduação, diretamente despachados da metrópole. A segunda é o meio cósmico, o ambiente físico em que todos se movem, o povo e os seus dirigentes, e onde um e outros haurem $o$ ar que respiram e o alento que lhes nutre as células, e que age como o seu relevo, a sua estrutura, o seu subsolo, a sua hidrografia, a sua flora, a sua fauna, o seu clima, as suas correntes atmosféricas e as suas intempéries. Tudo isto influi, tudo isto atua, tudo isto determina as ações dos homens na vida cotidiana - e, entretanto, nada disto parece se refletir na explicação da nossa gente (VIANNA, 1933[1923], p.56).

É à luz dessa perspectiva metodológica que emerge, como o próprio autor qualifica, o "caráter monográfico" de sua obra. Fica muito forte no conjunto de suas leituras a ideia de que em meio à totalidade de uma problemática complexa e ampla, alguns elementos devem ser separados e tratados exclusivamente para uma leitura mais aprofundada. Nesse sentido, Vianna foi bastante influenciado pela escola de Frédéric Le Play (1806-1882), cujo critério monográfico achou, então, o mais apropriado para o estudo do povo brasileiro. A respeito disso, afirmou:

Nos meus livros anteriores, (...) tenho investigado todos esses grupos de fatores da nossa formação e da nossa evolução histórica e social: o meio antropogeográfico (clima e solo), os fatores biológicos e heredológicos (linhagem e raça) e os fatores sociais (cultura), embora com outra tecnologia. Retomo agora (em Instituições políticas brasileiras), depois de dez anos de forçada interrupção, estes meus estudos sobre a nossa formação social (...). Por agora, irei investigar neste volume, e de forma monográfica e especializada, unicamente o papel da cultura na formação da nossa sociedade política e na evolução e funcionamento do Estado no Brasil (VIANNA, 1999[1949], p.90).

De alguma forma Vianna deixa implícito em suas argumentações que a sociedade brasileira não está totalmente formada, mas em processo de formação. Isso emerge justamente em questões levantadas sobre a composição étnica e racial da sociedade brasileira, pois, "no Brasil, a obra do caldeamento e fusão das raças não está ainda hoje inteiramente realizada: ainda subsistem em nossa população muitos elementos puros dos tipos étnicos fundamentais"(VIANNA, 1959[1932], p.70). $O$ autor não realiza afirmações contundentes acerca disso, mas parece acreditar que a formação de uma identidade nacional estaria contida na mescla entre as etnias e raças distintas. O "melting-pot" ou "caldeamento" que vinha ocorrendo na sociedade brasileira entre o "ariano", o negro e o indígena e intra os "diferentes tipos de arianos" formariam os "tipos antropológicos" mais adequados ao meio (social e físico) brasileiro. 
Entretanto, apesar de Vianna destacar a inevitabilidade desse processo de amalgama da população, cujos "puro-sangue arianos, concentrados nas camadas superiores (...) [acabariam] contaminados pelo sangue do negro e pelo sangue do índio, para ali carreados pela 'capitalização' progressiva dos mestiços superiores" (VIANNA, 1959 [1932], p. 72), também aponta para "forças de repulsão e defesa" que se tornaram bastante fortes após a migração em massa de europeus no início do século XX para o Brasil. A grande imigração europeia e a formação de núcleos coloniais, veio impedir o processo de miscigenação - entre negros, indígenas e "arianos" - e a consequente formação de "mestiços superiores". Isso, com incentivo do Estado, "acabou formando, no seio de populações circundantes, em regra mestiçadas, verdadeiras 'ilhas étnicas', onde só circula o sangue puro ariano (...) [Isso] equivale a dizer que, nas nossas regiões imigrantistas, o melting-pot, no sentido primitivo ou, melhor, no sentido colonial da expressão, não se constituiu" (VIANNA, 1959[1932], p. 73). Isso é dito, ainda que reitere que exista cruzamentos nessas colônias de imigrantes europeus, pois, "nelas assistimos ao mestiçamento de verdadeiras variedades humanas: a Celta, a Nórdica, a Eslavônica, a Ibérica, a Dinárica, a Atlântica. Raças estas, das quais algumas tão distantes e tão diferentes entre si, antropologicamente, como cada uma delas são do negro ou do índio" (VIANNA, 1959[1932], p. 73-74).

A formação de "ilhas étnicas" não era verdadeiramente um problema para Vianna, mas, algo que trazia uma série de questões para se meditar sobre o desenvolvimento de uma identidade nacional específica no Brasil. É nesse ínterim que, baseado na realidade estadunidense marcada pelo "enquistamento" das etnias que para ali migraram, Vianna alerta que para uma melhor condução do desenvolvimento da nação, o Estado brasileiro, pautado por critérios científicos, deveria interferir e conduzir o processo de assimilação das etnias imigradas da Europa; não somente no processo de entrada e alocação destes no território, como no próprio processo de seleção e caldeamento desses grupos e sujeitos. Ele, assim, fala em "leis de melting-pot nos países de imigração" que devem ser tomadas em conta para se pensar tal intervenção. São elas:

1) determinação dos coeficientes de homogeneidade (...) deles se podem inferir sugestões de ordem administrativas no sentido de reduzir esta condição de enquistamento ou de resistência à assimilação; 2) determinação dos coeficientes de fusão, isto é, discriminação percentual dos 
elementos constitutivos do melting-pot (..) É importante para o conhecimento da evolução étnica do grupo; 3) determinação do índice de fusibilidade. Estes índices nos permitem conhecer o grau de nupcialidade exogâmica dos elementos de cada etnia. É ele que nos dá meios de calcular as possibilidades de assimilação das etnias e as possibilidades da sua influência no grupo em fusão (...) no ponto de vista da assimilação das "culturas" e da mestiçagem dos "tipos antropológicos", este índice é, pois, da maior significação (VIANNA, 1959[1932], p.95).

Mesmo que Vianna expresse o desejo de ser objetivo e neutro em suas proposições, o autor expressa implicitamente em suas afirmações o desejo de branqueamento da sociedade brasileira. Isso é visível, pois, conduz toda sua argumentação para se pensar a absorção e aclimatação da "raça ariana" "superior", "civilizada", "bela” etc. -, enquanto negros e indígenas - "bárbaros", "inferiores", "selvagens" etc. - são visivelmente apresentados como um rejeito, senão para ser esquecido, que deveria ser eliminado no processo de absorção e assimilação. A mestiçagem só teria sentido para o autor se pudesse formar "mestiços superiores", em outros termos, "arianos" adaptados ao meio tropical.

É importante notar aqui que o meio tropical aparece como o nó górdio nas interpretações de Vianna. O autor não realizou extensas discussões sobre suas concepções sobre o que seria esse meio tropical. Parte de Sílvio Romero, cujos trópicos são vistos como um "clima e meio geográfico" sublime e indômito, marcado pelo "excessivo calor", "grandes secas", "chuvas torrenciais", "febres de mau caráter" etc. (ROMERO apud VIANNA, 1933, p. 29). Assim, uma vez que seria impossível transpor uma natureza dessa magnitude, o foco do autor se dá na compreensão e manipulação das raças e etnias para que essas se adaptassem aos trópicos, e não o contrário.

\section{OS PROBLEMAS DA RAÇA NA FORMAÇÃO NACIONAL BRASILEIRA}

Acompanhando o debate entre os cientistas europeus do início do séc. XX e a emergência de tendências que afirmavam a igualdade entre as raças e sua não importância para a compreensão das sociedades, Vianna argumenta contrário a essa tendência e, indo além, sublinha a impossibilidade de renunciar a categoria raça e as suas determinações no contexto brasileiro. Segundo ele, talvez essa questão não fosse um problema para os europeus, tendo em vista que vinham sofrendo um processo de caldeamento interno entre os diferentes grupos étnicos há 
cerca de 30 mil anos e a população era quase que uniforme. Contudo, na realidade brasileira, composta por raças tão diferentes, cujo encontro se deu há menos de 400 anos, era uma questão eminente e gritante. O "nosso problema étnico", como o denomina, é marcada pela "diversidade antropológica" e por "níveis de desenvolvimento desiguais" entre os "povos africanos, arianos e indígenas" que chegaram e se caldearam aqui, algo a que deveríamos nos atentar "para o bem da nação" (VIANNA, 1959[1932], p. 14).

Se seu mestre, Sílvio Romero (1902[1888]), havia em tempos anteriores enfatizado a necessidade de analisar cientificamente o negro e usar a ciência para sanar o empecilho do "problema etnográfico brasileiro", Vianna leva isso às últimas consequências. Indo além de seu mestre, buscou não só realizar estudos que supostamente sanariam demandas abstratas sobre as "questões de raça" no Brasil, mas que, também, teriam "uma utilidade pragmática" (VIANNA, 1959[1932], p. 69). Isso fica explícito em seus objetivos de pesquisa sobre raça e assimilação no Brasil:

\begin{abstract}
em suma, o que nós desejamos - os que investigamos, como antropossociologistas, como bio-sociologistas, como antropogeografistas, como demologistas e demografistas, os problemas da Raça - é que os nossos antropometristas e biometristas não dispersem os seus esforços e orientem as suas pesquisas no sentido de nos dar as bases científicas para a solução de alguns problemas mais urgentes e imperativos, como os que se prendem à formação da nossa nacionalidade no seu aspecto quantitativo e no seu aspecto qualitativo. Por exemplo: o problema da mestiçagem das raças. Ou o da seleção eugênica da imigração. Ou o da distribuição racional das etnias arianas, segundo o critério da sua maior ou menor adaptabilidade às diversas zonas climáticas do país. (grifo adicionado)
\end{abstract}

Ademais, para isso, afora ter utilizado todas as ferramentas científicas que lhe dispunha para deslindar esse "problema", pensava o Brasil - e as Américas - como uma região privilegiada para se realizar estudos desse tipo; o verdadeiro e mais apurado laboratório das raças. Isso Ihe dava autoridade científica sobre o tema, inclusive, para contestar afirmativas "tendenciosas"10, em sua visão, que vinham da

\footnotetext{
10"Ora, não é preciso grande esforço de penetração para compreendermos que, para esta brusca parada, para esta cessação tão súbita do interesse pelas pesquisas da raça, a causa determinante foi, sem dúvida, a influência exercida sobre o espírito dos nossos homens da ciência pelas teorias tendenciosas, construídas para contrabater a teoria da superioridade racial dos povos germânicos, desenvolvida principalmente pelos pensadores e antropologistas alemães. Basta confrontar a data em que essas teorias igualitaristas surgiram nos centros latinos e eslavos e a época em que cessou entre nós o interesse pelos problemas da patologia e da psicologia diferencial das raças, para nos convencermos de que essa nossa atitude de indiferença, de abandono, de desinteresse foi apenas um movimento reflexo, um movimento de imitação, daquela atitude
} 
Europa e arrogavam a igualdade entre as raças.

Não é possível, pois, sustentar nestes lados do Atlântico, onde as desigualdades étnicas se revestem de um relevo tão nítido, que os problemas de diferenciação das raças sejam problemas sem interesse. $\mathrm{O}$ fato de terem afluído para aqui etnias vindas de todos os continentes torna a América, ao contrário, o centro por excelência dos estudos da Raça, quer no ponto de vista da antropologia física, quer no ponto de vista da antropologia social, especialmente nos seus aspectos biológicos. Os fenômenos da Raça mostram-se aqui em estado de elaboração contínua: nós os temos, por assim dizer, sob as nossas vistas, visíveis a olhos nus - e tudo é como se estivéssemos observando numa retorta as fases uma reação química. Os fenômenos de hibridação podem aqui ser estudados com uma amplitude e uma precisão impossíveis no mundo europeu porque só aqui se dá a mestiçagem de raças extremamente distintas, o que nos permite observar os fenômenos heredológicos, oriundos desses cruzamentos em condições ótimas de visibilidade. É um privilégio todo nosso, de que não podem gozar os observadores dos mesmos fenômenos quando operados unicamente nos centros de origem dos grupos brancos (VIANNA, 1959[1932],p.14-15, grifo nosso).

Frente a isso, do ponto de vista analítico, Vianna enxergava dois empecilhos metodológicos existentes e difundidos entre a intelligentsia brasileira. O primeiro envolvia as já mencionadas teorias sobre a "igualdade das raças", tendências absorvidas em um "movimento de imitação" realizado pelos cientistas brasileiros. Isso vinha contribuindo "para criar em torno da psicologia diferencial das raças um ambiente de equívocos, que tanto está dificultando ainda hoje [1932], o estudo desse problema delicado, por certo o mais delicado e importante problema da antropologia social [brasileira]" (VIANNA, 1959[1932], p.18).

De acordo com o autor, esse fato conduziu para que houvesse uma gradativa diminuição das investigações sobre a composição racial de nossa sociedade nos anos que se seguiram a formação da República. Bem como, levou a que cientistas que se empenharam em estabelecer a discriminação dos caracteres diferenciais e as reações a estímulos vindos do meio ("social" e "cósmico") das três raças formadoras da nossa nacionalidade, conformassem premissas errôneas, que previam que cada "tipo antropológico" possuiria "uma individualidade própria, uma maneira peculiar, uma forma específica de reação" (VIANNA, 1959[1932], p.16).

Outro fator que tornava nebulosa a compreensão da raça na sociedade brasileira, na visão do autor, era a "confusão trazida à compreensão da psicologia p.18. grifo adicionado). 
das raças pela noção das 'raças nacionais' e das 'raças históricas'”, pois, "o que tem sido feito até agora com o nome de psicologia diferencial de "raças" não tem sido outra cousa senão má ou boa psicologia diferencial de "povos", ou mais propriamente, de 'etnias'”' (VIANNA, 1959[1932], p. 18)

Isso se deu porque à época

\begin{abstract}
não haviam ainda atingido a exatidão que atingiram na atualidade, nem as pesquisas antropométricas se haviam realizado com extensão e a sistematização da época atual. Alemães pensavam então que eram formados de uma raça única; que todos eles pertenciam, apesar das suas variações individuais, a um mesmo tipo antropológico, isto é, à mesma "raça" germânica dólico loura (h. europeus). (VIANNA, 1959[1932], p.19)
\end{abstract}

De acordo com Vianna, este era um grande equívoco, nascido do falso conceito de homogeneidade étnica dos diversos "grupos nacionais ou históricos". O que desapareceu em face dos resultados da análise antropométrica, a qual os investigadores modernos submeteram esses diversos "povos". Cada um desses grupos nacionais, cada uma dessas etnias, era composta de várias raças, isto é, "de vários tipos antropológicos, caracterizados por atributos diferenciais, descritiva e antropometricamente determinados" (VIANNA, 1959[1932], p. 20). Enfaticamente, profere o autor acerca disso: "essas psicologias da raça não passam de psicologia de coletividades, de grupos nacionais - de etnias (...) Compreende-se agora a série de equívocos, confusões, mal-entendidos e contradições que naturalmente surgiram dessas idéias tão errôneas sobre a composição étnica das nacionalidades européias e sobre a psicologia das suas raças formadoras" (VIANNA, 1959[1932], p. 21).

Há, assim, uma "confusão" justamente na leitura dos conceitos de "psicologia de etnia" e "psicologia de raça", segundo ele, "duas ciências distintas". Em seus termos, há dois ramos da psicologia que se distinguem e articulam para pensar o ethos de uma população nacional:

a) a psicologia das etnias - ciência social, ramos da psicologia coletiva, estudando o que chamamos a "alma dos povos", produto complexo, para cuja formação contribuem todas as forças elaboradoras da civilização e da evolução histórica dos povos: o meio fisiográfico, o clima, os agentes econômicos, os choques de culturas, as migrações, as lutas de classes, mil outros fatores, inclusive a "raça", no sentido zoológico ou morfológico.

b) a psicologia das raças - ciência natural, ciência puramente antropológica, para a qual a raça é um fato biológico e psicologia da raça uma pura questão de psicofisiologia humana, nada tendo que ver, pelo menos imediatamente, com a psicologia dos grupos sociais (nacionalidade, povos, etnias) (VIANNA, 1959[1932], p.23)

As operações teóricas de Vianna para pensar o Brasil seguem uma lógica 
estratégica, pois, flexibiliza a noção de raça para pensar o nacional ao enfatizar que há diferenciações raciais no interior de formações nacionais (ou "coletividades étnicas"). Com isso é destacado que, ainda que haja uma "psicologia nacional" que defina a mentalidade (ou a "alma das nações"), essas agremiações são compostas, na prática, por uma diversidade de "tipos morfológicos ou raciais".

Com essa ação, ao mesmo tempo em que Vianna anula o discurso que define a nacionalidade como uma população racialmente monolítica e cristalizada, apresenta uma conjuntura mais favorável e promissora para se interpretar o Brasil, país que possui uma população étnica e racialmente diversa. Da mesma forma, também, abre um campo repleto de possibilidades de intervenção na sociedade brasileira, posto que via na ciência uma ferramenta de intervenção e transformação da realidade.

Porém, apesar de relativizar as diferenças raciais presentes nos "grupos étnicos" nacionais, persiste em Vianna ainda ideias essencialistas que preveem na raça um determinante individual e social. Mais uma vez ele se utiliza das "ciências mais avançadas" para realizar suas ponderações e afirma:

Diante das revelações trazidas pelos teoristas dos 'tipos constitucionais' (...) não há mais razão para que se ponha em dúvida a possibilidade de uma correlação entre os tipos somatológicos chamados 'raças' e os tipos de inteligência e de temperamento descritos pelos psicofisiologistas, psicometristas, nosologistas em geral (...) Os estudos da biotipologia contemporânea estão, realmente, demonstrando que há uma conexão muito íntima entre os aspectos morfológicos do indivíduo e as peculiaridades da sua fisiologia, da sua patologia e da sua psicologia (temperamento, inteligência) (VIANNA, 1959[1932], p. 26-27).

Partindo dessa leitura, "a conclusão é que a raça é, em última análise, um fator determinante das atividades e dos destinos dos grupos humanos" (VIANNA, 1959[1932], p.42). Em outras palavras, a raça é um aspecto central para o progresso da nação. É por isso que, em sua interpretação, uma nação não pode se colocar indiferente, nem a qualidade, nem a quantidade, dos elementos raciais em que consiste a sua composição populacional, pois, os "tipos raciais de constituição" determinam os arquétipos de temperamento e de inteligência preponderantes na "massa social" (VIANNA, 1959[1932], p. 39-40)

Vianna, assim, demarca as características de cada "tipo racial". O "significativo" de seu modelo teórico é que, "em princípio, nenhum atributo da psique 
humana é privativa desta ou daquela raça, como queriam fazer acreditar os antigos psicologistas de raças. Esses atributos apenas devem-se revelar mais frequentemente neste ou naquele tipo antropológico" (VIANNA, 1959[1932], p. 39). Ainda que afirme que características de temperamento e inteligência não sejam monopólio de um único tipo racial, estabelece hierarquias, cujo "ariano" é tomado como superior. Nesse sentido, dentre o grupo de "tipo ariano" predominaria indivíduos com "características psicológicas superiores", o que, mais facilmente, acarretaria a formação de uma "civilização moderna"11.

Nesse contexto em que tipos raciais são delimitados em "arianos", "negros" e "índios", algo que aflige Vianna é o mestiço. Como ficaria o mestiço nessa fórmula que afirma propensões de faculdades subjetivas em grupos raciais bem definidos? Segundo ele, os mestiços também reproduzem em si a correlação entre "tipo morfológico" e o "tipo psicológico", pois, por exemplo, "quanto maior a soma de sangue indígena do indivíduo e, portanto, quanto mais o tipo do indivíduo se aproxima do tipo morfológico do índio, tanto mais estes indivíduos reproduzem, nas suas condições intelectuais, as características intelectuais do índio, e vice-versa" (VIANNA, 1959[1932], 35-36). A "psicologia" de um mestiço dependeria das características predominantes herdades dos tipos raciais básicos.

Do mesmo modo, Vianna, em suas argumentações, chama a atenção para o fato de que em cada tipo há uma grande diversidade interna. Por exemplo, ressalta ele, o grupo branco não é constituído de um único tipo, ele é complexo e diverso, composto por todos os grupos brancos constituídos na Europa. Ao pensar os efeitos "científicos" dessa pluralidade intra grupo, diz o autor:

\footnotetext{
${ }^{11} \mathrm{Em}$ comparação com a "raça negra", "as duas raças são desiguais - e esta desigualdade se reflete na desigualdade da riqueza eugenística das suas elites respectivas. Ora, como a civilização moderna é muito exigente destes tipos superiores na composição das suas elites, compreende-se e explica-se porque o negro, vivendo dentro desta civilização, revele certa inferioridade em face dos grupos brancos e brancóides com os quais convive (...) É claro que esta inferioridade relativa do negro só é suscetível de determinação segura, ou melhor, de pré-determinação quando consideramos os negros em grupos, formando uma população; individualmente, isto é, para cada caso isolado, é absolutamente impossível saber-se se um dado negro é um tipo superior ou um tipo inferior, é um supernormal ou um subnormal - um gifted [bem-dotado] ou um dull [estúpidos] (...) Esta desigualdade entre as duas raças só se revela, como já dissemos, quando os seus indivíduos se apresentam reunidos em grandes massas. Nesse caso, há quase certeza matemática nesta conclusão: de que um grupo de 10 mil negros há de se mostrar incomparavelmente mais rico em dulls do que um grupo de volume igual, formado exclusivamente por tipos arianos ou semitas, por exemplo." (VIANNA, 1959[1932], p.196-197).
} 
dentro de objetivos meramente antropométricos, é possível que se possam desprezar essas diferenciações biotipológicas que se manifestam entre os elementos do grupo branco (europeus de origem e descendentes); mas, no ponto de vista da bio-sociologia, da psicologia étnica e da antropossociologia, êste grupo formado por elementos tão heterogêneos torna-se, na verdade, imprópria para qualquer utilização científica (VIANNA, 1959[1932], p. 47).

Essa leitura é realizada por Vianna tendo subjacente as questões que envolvem o meio "cósmico" e o clima, pois, na Europa, meios e climas distintos parecem ter conformado diferenciações no interior do "tipo ariano". Essa ação é mobilizada exatamente para se fazer a reflexão sobre a adaptabilidade dessa "diversidade do tipo ariano" aos meios e climas brasileiros. Pois, "como então fundirmos todos êstes brancos - ibéricos, dináricos, celtas, nórdicos, tão diferentes uns dos outros - num só grupo e realizarmos com êles investigações sobre aclimatabilidade, como se estivéssemos diante de uma série homogênea, composta de um tipo antropológico único?" (VIANNA, 1959[1932], p.51)

Criticando alguns cientistas brasileiros e organismos estatais sobre a ineficácia - do ponto de vista prático - de tratar os tipos raciais genericamente, afirma Vianna que:

parece-nos impossível chegarmos a resultados fecundos, se nos abstinarmos em tratar, em nosso meio, indistintamente, como se fôssem a mesma cousa o colono italiano, vindo da Basilicata, que é um puro Ibero, o colono alemão, vindo do Hanôver, ou o Holstein, que é um puro Nórdico, o colono iugoslavo, vindo da Bósnia ou da Croácia, que é um puro Dinárico, e o colono russo, vindo da Ucrânia, que é puro Celta. Êste nivelamento pode ser muito legítimo para os efeitos censitários - de estatística demográfica. Mas, em morfologia da raça não; em biologia da raça, não; em sociologia da raça, não (VIANNA, 1959[1932], p.61).

No nosso próprio território, segundo ele, unificar os "tipos brancos" anularia, no plano "biométrico" e "biosociológico", "as diferenciações que a seleção natural fatalmente está estabelecendo, em nosso meio, entre as diversas etnias" (VIANNA, 1932[1959], p. 53). Em sua visão, ao operar com estas várias etnias como se elas fossem equivalentes na sua "capacidade de resistência biológica, nas modalidades da sua "resposta adaptativa" ao nosso meio", não chegaríamos a nenhuma solução "aproveitável". Além disso, isso dificultaria uma intervenção pragmática, pois, não se teria maneiras palpáveis para inferir quais seriam os "tipos" que, ao sobreviverem ao escrutínio seletivo, viriam a dar "à nossa população nacional a sua caracterização antropológica e étnica definitiva" (ibdem, p. 54). 


\section{PARA UM PLANEJAMENTO REGIONAL DA ALOCAÇÃO ARIANA NO BRASIL}

Antes de entrar nas considerações de Vianna acerca da relação raça, meio e planificação, deve-se ressaltar que o autor, ao se debruçar sobre os processos de assimilação e adaptabilidade aos meios brasileiros, se restringiu apenas ao que qualificou como "tipo ariano", denominados também como "caucasianos". Como já evidenciado, negros e indígenas eram apresentados em uma linguagem "científica" como "inferiores" e com uma "psicologia" - fruto de suas racialidades - inaptas para a construção de uma "civilização moderna". O fato de não tratar de negros e indígenas em suas discussões sobre a adaptação das raças ao meio e ao clima tropical, revela que, por trás de seu projeto de uma nação estava fora de cogitação as "raças inferiores". Paradoxalmente, essas "raças" eram sua preocupação permanente, mas, no sentido de serem extirpadas do território.

Nesse sentido, buscou exatamente verificar como a diversidade racial branca $^{12}$ - que envolvia europeus de origem "Celta", "Mediterrânea", "Nórdica", "Ibérica", "Dinárica" etc. - se relacionavam com o meios brasileiros, mais exatamente, com o climas tropicais aqui existentes, pois, "cada qual dêsses tipos tem uma 'resposta adaptativa' própria aos climas tropicais" (VIANNA, 1959[1939], p. 49). A partir dessa constatação ele estava buscando "extrair conclusões de ordem prática, capazes de nos orientar sobre o problema de uma distribuição mais racional das etnias nórdicas, das etnias celtas e das etnias ibero-mediterrêneas em nosso território" (VIANNA, 1959[1932], p. 54).

Para realizar tal discussão, Vianna se fundamenta em uma bibliografia extensa - composta majoritariamente por publicações estadunidenses - sobre as experiências coloniais em África, Austrália, Ásia e América ${ }^{13}$. Dois fatos de sua

\footnotetext{
${ }^{12}$ Deve-se destacar que o Vianna usa noção de "povo ariano" como sinônimo de "raça branca", ao incluir Homo Alpinus e o Meridionalis. Em outros termos, o autor distorce a classificação de Lapouge, para quem os "arianos" seriam os Homo Europaeus; ou seja, dolicocéfalos (índice cefálico abaixo de 75), louros, de olhos azuis, altura em torno de 1,70, concentrado na Inglaterra e países nórdicos. 0 autor realiza tal operação para fugir das visões pessimistas que se sobrepunham aos povos que formaram a população brasileiro, especificamente os portugueses. O grande problema é que o ele não comunica, discute ou justifica a realização de tal operação" (cf. CARVALHO, 2000).

13 Suas leituras se fundam, principalmente, em artigos publicados no periódico estadunidense Geographical Review da The American Geographical Society: Emory Ross, The climate of Liberia and its effect on Man (1919); Gruffith (sic) Taylor, The settlement of tropical Australia (1919); Mark
} 
interpretação acerca dessas referências parecem ser importantes para 0 desenvolvimento de suas leituras. Primeiramente, ele parte da premissa de que o clima e o meio influencia física e subjetivamente os grupos humanos, consequentemente, define o "ethos" ou "caráter" da população que se formará em um determinado meio. Dentre todos os meios e climas, o tropical é o menos qualificado para a formação de uma "civilização superior" ou "civilização moderna". Segundo, apesar dessa orientação, Vianna não chega a conclusões em suas leituras sobre a adaptação do "tipo ariano" no Brasil, pois, conforme diz, seria necessário um conjunto maior de dados sobre os "tipos antropológicos" dessa população existente no país. No entanto, aponta para a existência de diferenças marcantes no processo de adaptação dos diversos tipos de europeus ao clima tropical. Essa pré-visão seria fundamental para se meditar sobre os processos brasileiros de adaptação, pois, "nos climas tropicais, as diversas raças arianas não tem a mesma capacidade de aclimatação, de respostas adaptativas (...) há diversos climas tropicais, e as diversas etnias europeias não se aclimatam com a mesma facilidade em todas as regiões quentes" (VIANNA, 1959[1932], p. 48).

Dois exemplos extremos são tomados como referências para analisar os efeitos diferenciais do meio no "tipo ariano": a "raça Nórdica" e o "grupo [raça] Mediterrâneo".

Os grupos formados por etnias de raça Nórdica parecem revelar sensível incompatibilidade com os climas de tipo tropical, principalmente os equatoriais. É unânime o conceito entre os antropologistas e técnicos em medicina tropical, de que o Nórdico não pode aclimatar-se nas regiões megatérmicas do globo, entendendo-se aclimatação no sentido que lhe dão os modernos ecologistas e antropogeografistas (...) Nos centros tropicais de colonização nórdica, os estigmas de degenerescência se revelam de uma maneira muito frequente entre os [seus] "descendentes" (VIANNA, 1959[1932], p. 49).

Quanto à raça Mediterrânea:

ao contrário dos elementos do grupo Nórdico, revelam uma inegável capacidade de adaptação aos climas tropicais, mesmo em "descendentes" de terceira e quarta gerações, não se encontra nenhum sinal sensível ou

Jefferson, An American colony in Brazil (1928); Dunlop, Queensland and Jamaica (1926), assim como, nas obras de Ellsworth Huntington, Civilization and climate (1923); Aldo Castellani, Climate and acclimatization (1931); Courcy Ward, The problem of white acclimatization in the tropical regions (1930); Germano Correia, Les luso-descendants de I'Inde Portugaise, Goa (1928) e Les lusodescendants de l'Angola, Nova Goa (1930); Bento Carqueja, O povo portugués (1916); Robert Michels, Lavoro e razza (1924); C. C. Carlson e Fred A. Huntington, Environmental Basis of Social Geography Hardcover (1929); e Lucien Cuénot, L'adaptation (1925). 
positivo de degeneração, nem física, nem no moral. É, pelo menos, o que acaba de observar o professor GERMANO CORREIA para os lusosdescendentes da Índia e da África (VIANNA, 1959[1932], p. 51).

Algo que é importante notarmos na leitura que Vianna realiza sobre o "tipo ariano", é o fato de as diferenças no interior desse grupo serem tomadas em consonância com a localização de determinados meios, na verdade, climas. Não é realizado um discussão aprofundada sobre a ação do meio na diferenciação racial ou mesmo se existem meios exatos para cada tipo racial europeu, contudo, como se percebe, a terminologia utilizada para qualificar a diferenciação intra-grupo "ariano" remetesse a localizações que se predispõe na Europa de Norte a Sul, consecutivamente, "Nórdicos" e "Mediterrâneos"; falando de outra maneira, os extremos latitudinais do continente que indicam, supostamente, as localidades mais quentes e mais frias, as regiões mais distantes e mais próximas dos trópicos.

A proposta de Vianna, à vista disso, seria de esquadrinhar o meio próprio e harmônico para cada "tipo ariano" e, a partir disso, definir as regiões compatíveis para cada tipo de imigrante no território brasileiro. Somente assim poderia ser realizada, tanto a "selecção eugênica da imigração (...) [quanto] a distribuição racional das etnias arianas segundo o critério da sua maior ou menor adaptabilidade ás diversas zonas climáticas do país" (VIANNA, 1959[1932], p. 65, grifos adicionados) ${ }^{14}$.

Como se nota, para solucionar "um problema prático, de urgência imperiosa em nosso país", Vianna orienta seus esforços no sentido de um tipo de planejamento regional que visa a "distribuição, em nosso território, dos diversos 'tipos' ou das diversas 'etnias' européias, segundo o critério da sua maior ou menor

\footnotetext{
${ }^{14}$ De maneira mais detalhada: "Os nossos tipos hão de surgir da observação prévia da nossa população ao norte, ao centro e ao sul, na região da costa e na região do sertão. Obtida a discriminação deles pelo processo preliminar da observação, só então estes "tipos" deverão ser tratados antropometricamente, isto é, estudados nos seus característicos morfológicos e, depois, biotipológicamente, isto é, nas suas características funcionais; de maneira a determinar os "tipos constitucionais" mais frequentes em cada um deles e, portanto, as modalidades mais características da sua fisiopsicologia (...) [E complementa] em síntese: adotando este método para o estudo antropológico da nossa população, teríamos que isolar: a) os tipos negros, descendentes dos que vieram com as importações africanas do período imperial; b) os tipos aborígines (que de modo algum podem ser unificados num só tipo, o mongólico); c) os tipos brancos que, pelo menos, devem apresentar aqui as quatro ou cinco modalidades que apresentam na Europa; d) os mestiços de vários tipos, elaborados nestes quatrocentos anos de mestiçagem intensa, representando os resultadossínteses da ação combinada da hereditariedade e da seleção mesológica." (VIANNA, 1959[1932], p. 65-67).
} 
aclimatabilidade" (VIANNA, 1959[1932], p. 55). Isso é pensado para que essa população não fosse concentrada apenas em algumas partes do país, levando "capital eugênico" para todas as partes; e, para que raças não adaptáveis a certas regiões não perdessem seu "potencial eugênico" devido a sua incompatibilidade a certos climas.

Dessa forma, assevera Vianna (1959[1932], p. 65):

\begin{abstract}
os nossos tipos hão de surgir da observação prévia da nossa população ao norte, ao centro e ao sul, na região da costa e na região do sertão. Obtida a discriminação deles pelo processo preliminar da observação, só então estes "tipos" deverão ser tratados anthropometricamente, isto é, estudados nos seus caracteristicos morphologicos e, depois, bio-typologicamente, isto é, nas suas caracteristicas funccionaes; de maneira a determinar os "typos constitucionaes" mais frequentes em cada um deles e, portanto, as modalidades mais características da sua physio-psycologia (grifos adicionados).
\end{abstract}

Por fim, a mestiçagem ainda parece uma questão para Vianna. Ele aponta para a existência de dois processos de mestiçagem existentes no Brasil: uma mestiçagem intra-grupo ariano e outra entre o brancos e os "tipos bárbaros" (indígenas e negros). Ambos os processos devem recair em um "trabalho preliminar de observação" (VIANNA, 1959[1932], p. 63), e, no que se refere ao primeiro, é ressaltado apenas que se deve ficar atento à multiplicidade dos tipos mestiços e quais são aqueles que mais sobrevivem à ação "destrutiva dos agentes mesológicos [tropicais]". A partir disso, verificar quais desses tipos sobreviventes oferecem condições de estabilidade capazes de elevá-los à categoria de "blenótipos sólidos" ou "stable-blends" [misturas estáveis], em outros termos, os tipos ideias para os meios onde estão.

No que toca ao segundo processo, é deixado implícito que na mestiçagem entre os "tipos brancos" e os "tipos bárbaros", deve-se encontrar os "fenótipos sólidos". Vianna não entra em detalhes sobre o que seriam os "fenótipos sólidos", contudo, no decorrer do texto dá a entender que esses seriam fenótipos mais próximos do "tipo ariano", fruto de uma "seleção natural" - que envolveria "seleção reprodutiva", "fecundidade e mortalidade diferencial", "seleção matrimonial", "índices de fusibilidade" etc. - que favoreceriam para esse tipo. 


\section{CONSIDERAÇÕES FINAIS}

Para posicionar a produção de Vianna em um contexto, é importante notar que $\mathrm{o}$ autor se encontra no ponto de transição entre as ideologias do racialismo científico e da democracia racial no Brasil. Como aponta Skidmore (1976), ele foi o último pensador brasileiro de peso a teorizar sobre a "superioridade ariana", além do que, utilizando-se de uma série de categorias, na verdade jargões ("ariano", "caucasiano", "bárbaro", "superior-inferior"), ultrapassados e tidos como démodé no próprio centro de produção de conhecimento que os criou, a Europa e os Estados Unidos. Ainda assim, não se pode, nem subestimar a imaginação teórica de Vianna, nem o sentido político de suas teorias e teses.

Quando Vianna publica Raça e Assimilação em 1932, as "questões de raça" já não eram mais um problema tão forte no imaginário das elites quanto era no fim do século XIX e primeira década do século XX. A entrada em massa de imigrantes europeus e as teses de um branqueamento progressivo da população ${ }^{15}$ - retificadas pelos números dos censos que demonstravam a diminuição da população negra e indígena frente ao aumento da população branca, acalmavam as elites quanto a "inferioridade" negra, indígena e mestiça. Como uma série de autores apontam, Vianna expressava conclusões deveras otimistas acerca do branqueamento da nação (SKIDMORE, 1976; COSTA, 2006) ${ }^{16}$ e mesmo que ele fosse inconsistente ou utilizasse uma terminologia inadequada, o que importava e era notado, principalmente pelas elites, era que o Brasil estava se tornando um país branco, consequentemente, "civilizado".

Talvez por isso Vianna não tenha se preocupado em tratar da inferioridade

\footnotetext{
${ }^{15}$ Baseados em estatísticas que demonstravam o aumento da população branca em detrimento do declínio da negra, indígena e mestiça, vários "homens de ciência" vinham fazendo séries de projeções sobre o "branqueamento" da nação. Certamente o mais famoso foi o realizado pelo diretor do Museu Nacional, o antropólogo João Batista de Lacerda. Ao apresentar suas investigações como representante oficial brasileiro durante o I Congresso Internacional das Raças (Londres, 1911), concluiu, "otimista", que em 100 anos, como demonstravam os números, a população brasileira seria praticamente composta por brancos.

${ }^{16}$ Esses autores ressaltam que Vianna estava deslocado no tempo, que suas proposições emergiam enquanto na Europa esse tipo de leitura racista entrava em descrédito, contudo, devemos pontuar que a bibliografia utilizada por Vianna era o que havia de mais novo e atual da ciência à época. Isso nos dá indício de que a produção de discursos científicos racilistas não cessou tão rapidamente, talvez tenha deixado de ser hegemônico, contudo continuaram surgindo, principalmente em países colonialistas e imperialistas, como os Estados Unidos, fonte de onde fartamente Vianna bebeu.
} 
dos "bárbaros" ou "elementos negros e indígenas" em Raça e Assimilação. Isso só é realizado com mais profundidade no último capítulo em resposta às críticas de Arthur Ramos à sua crença na hierarquia de raças. Na medida em que tudo indicava que o branqueamento da sociedade brasileira era certo, o autor estava livre para tratar apenas dos imigrantes eurobrancos. Assim, dedicou-se quase que exclusivamente nessa obra a discutir e a elaborar proposições para otimizar os processos de alocação das "raças superiores", leia-se, "arianos" no território brasileiro.

Certamente as questões mais difíceis de transpor eram as que envolviam a mestiçagem e o meio tropical degenerante, frente a imigração eurobranca. Assim como a miscigenação era um processo irreversível na população brasileira, o meio e clima tropical era imanente ao território. Talvez por isso estes fossem temas motrizes nas proposições de Vianna. Então, qual ou quais foram suas saídas?

Primeiramente, ainda que se fundamentasse em um conjunto de teorias racialistas rígidas e monolíticas e se referisse constantemente a raças "inferiores" e "superiores", não via tais diferenças como absolutas. De acordo com Skidmore (1976, p. 220),

esse era, na realidade, o compromisso de que os brasileiros se vinham valendo, para poder reconciliar a teoria racista com sua realidade multiracial. Inconsistente, como isso possa ter parecido aos racistas ortodoxos da Europa e da América do Norte, Oliveira fez desses graus de inferioridade o conceito central da sua interpretação da evolução racial do Brasil.

É nesse sentido, também, que Vianna enfatiza que não existiam nações racialmente homogêneas e que, entre a própria "raça ariana", existiam diferenças e processos de "melting-pot", de mistura. No subentendido de suas conclusões, o fato de o Brasil ser uma nação multirracial não Ihe excluía as chances de se tornar uma civilização, como demonstravam seus parâmetros europeus e, mesmo, os Estados Unidos.

Igualmente, mesmo que Vianna acreditasse na influência degenerante do meio e clima tropical e admitisse os "efeitos biológicos e psicológicos" destes sobre a "raça ariana", ele assinala que esses efeitos eram relativos; entre os "tipos arianos" a ação do meio era explicitamente matizada. Aqui entendemos porque ele renega o "fatalismo geográfico de Ratzel" e se ampara no "possibilismo de La Blache", como já apontado. O meio tropical não era um problema, mas um horizonte de 
possibilidades, desde que o processo de alocação de imigrantes fosse otimizado pelo poder da ciência. Daí a necessidade de se pesquisar os "tipos arianos" e os tipos adequados para cada meio-clima específico no território brasileiro, pois, "se as etnias europeias possuem cada uma delas um modo específico de reação ao clima tropical, compreende-se a necessidade de destacar do grupo branco as 'raças' que o compõem, para poder determinar, com segurança, a aclimatabilidade diferencial de cada uma" (VIANNA, 1959[1932], p. 51).

Algo que se deve destacar, é o fato de que, mesmo que o discurso científico de Vianna pudesse ser considerado antiquado e obsoleto nos anos 1930 - na medida em que isso se encontrava em um contexto de relativa suspensão das leituras racialistas no Brasil, exibe entre suas referências bibliográficas tanto produções que defendiam o determinismo racial e geográfico, quanto os autores que buscavam desconstruir os discursos que enfatizavam as determinações (naturais e biológicas) nos processos sociais. Podemos citar como autores do segundo grupo, o antropólogo alemão radicado nos Estados Unidos, Franz Boas (1858-1942) ${ }^{17}$, o antropólogo estadunidense, Melville J. Herskovits (1895-1963) e o sociólogo estadunidense, Robert Park (1864-1944) ${ }^{18}$. A título de exemplo, esses foram os mesmos autores que Gilberto Freyre em Casa Grande \& Senzala (1934) tomou como referência para formular suas ideias de "uma democracia étnica no Brasil". Contudo, com Vianna, ou foram contestadas suas teorias, ou tomadas partes específicas para legitimar suas pressuposições sobre a assimilação e a adaptação do "tipo ariano" nos trópicos. Isso demonstra que estava bastante incrustado em sua perspectiva teórica ideias de fundo determinista-biologicista, algo que as novas teorias "culturalistas" não desataram facilmente.

Algo interessante acerca dessas elaborações teóricas de Oliveira Vianna, como nota Bresciani (2007), é que ainda que todas as interpretações do autor o

\footnotetext{
${ }^{17}$ Por exemplo, Franz Boas (1966), que possuía formação básica em Geografia, desenvolveu uma teoria que ficou conhecida como "relativismo cultural". Essa perspectiva afirma que todos os seres humanos são naturalmente iguais, que o comportamento se desenvolve no contexto de aprendizagem social e que as sociedades podem ser melhor compreendidas através da observação imparcial. Suas ideias trouxeram uma mudança profunda para o estudo antropológico e alimentou 0 seu subsequente ativismo pela igualdade racial e de gênero.

${ }^{18}$ As obras citadas são: Melville J. Herskovitz, The American Negro (1928); Robert Park, Human migration and marginal man (American Journal of Sociology, Maio, 1928, págs. 891-3); e Franz Boas, Changes in the bodily form descendants of immigrants (1910).
} 
levassem a conclusões que o fracasso do desenvolvimento social brasileiro estava relacionado a uma estrutura social que se reproduzia por desigualdades "sociais", ele ainda insiste a relegar o atraso nacional a fatores naturais ou biológicos, do meio e da raça principalmente.

Não há uma explicação unânime na historiografia acerca disso. Há autores, como Carvalho (1991, 2000), que afirmam que as discussões racialistas e deterministas do autor eram algo apenas alegórico e uma formalidade científica, justamente para ficar em dias com as leituras científicas europeias. Era comum entre a comunidade científica brasileira à época citar autores estrangeiros a pompa para simular um discurso científico, mesmo que de forma distorcida. Só assim autores brasileiros eram reconhecidos e respeitados. Por isso Vianna reproduzia ideias deterministas e racialistas em suas leituras, algo que, ao fim da conta, era apenas uma prática retórica e não afetava o cerne de suas teorizações. Não por acaso, segundo Carvalho, as teses racialistas foram abandonadas por uma discussão sobre a função e papel do Estado na formação e organização sócio-cultural-política brasileira ainda nos anos de 1930.

Por outro lado, há autores que dão a entender que as teorizações racialistas e deterministas nunca cessaram em Vianna. Ainda que tenham sido modificadas as terminologias - pós 1930 principalmente, as ideias que defendiam uma supremacia branca à brasileira estiveram sempre presentes, explícitas ou codificadas, em suas teorizações (BRESCIANI, 2007; SKIDMORE,1976; COSTA, 2006). Na primeira fase de sua produção, esteve presente desde Populações Meridionais (1920) e encontra seu ápice em Raça e Assimilação (1932). Já na segunda fase, nas obras voltadas para a política e organização do Estado, tornam-se rarefeitas teorizações racialistas, como uma mudança de foco, mas não desaparecem.

Essa questão carece de um trabalho específico, mas, nota-se que Vianna é uma referência que aparece constantemente em obras e textos geográficas que vão dos anos de 1930 até a década de 1970. Por exemplo, suas leituras sobre as três "zonas" brasileiras de organização social que articulam mesologia e população foram uma das referências de Delgado de Carvalho em Geographia do Brasil (1927) para pensar a unidade da diversidade regional no Brasil. Vianna, também influenciou as proposições geopolíticas de Everardo Backheuser sobre o Brasil, em especial 
sobre organizar o país em torno de um Estado centralizado - em contraposição ao federalismo republicano - e sobre suas orientações pelo branqueamento para a solução dos problemas raciais e mesológicos (cf. ANSELMO, 2000,p.48-49). Do mesmo modo, o texto Evolução do povo brasileiro (1922) foi uma das referências de Milton Santos em O Povoamento da Bahia (1948) para analisar a fixação populacional no sertão nordestino pela criação gado.

Frente a todas as referências de Vianna entre geógrafos, talvez o caso mais emblemático (e trágico) seja o texto de Aroldo de Azevedo (1975[1969]). O autor reproduz acriticamente, não somente o cabedal teórico e categorias raciológicas de Oliveira Vianna, como, os estereótipos que o autor definiu em suas discussões sobre o "povo brasileiro". Por exemplo, Azevedo (1975[1969], p. 122-123) apresenta como factíveis as tipologias racialistas de Oliveira Vianna, como o de que "[o mulato] não possui grande disposição para os trabalhos pesados, nem muito inclinação para o comércio ou a indústria" ou de que "[os caboclos] podem tornar-se traiçoeiros e vingativos, por vezes fanáticos em matéria religiosa". Isso é feito, paradoxalmente, valorizando o "caráter mestiço" de nossa sociedade, o "principal aspecto da população brasileira" (idem, p. 120), e mediante a afirmação de que é "inegável (...) que predominem no Brasil os indivíduos de cor branca, oriundos de troncos europeus e asiáticos" (idem, p. 114). Em suma, Azevedo se apropria e utiliza dessas discussões em um momento em que já se evidenciava o caráter defasado, falacioso e distorcido das teorias raciológicas de Vianna.

Por fim, como a natureza da geografia na história das ciências é sempre contestada e negociada (LIVINSTONE, 1992), talvez a discussão que apresentamos aqui nos permita vislumbrar, não somente articulações mais amplas entre "pensamento social brasileiro" e o "pensamento geográfico", como pensar os efeitos sociais das teorias geográficas.

\section{REFERÊNCIAS}

ALVES FILHO, A.(org.). (2011) Oliveira Vianna: uma introdução ao estudo da formação social brasileira - pioneirismo, contribuições e questões polêmicas. Rio de Janeiro: Miguel Cervantes.

ANSELMO, R. de C.. (2000) Geografia e Geopolítica na formação nacional brasileira: Everardo Adolpho Backheuser. Tese Doutorado em Geografia. Unesp- Rio Claro. 
AZEVEDO, A. de. (1975[1969]) Geografia do Brasil. São Paulo: Ed. Nacional.

BERDOULAY, V. (2013) A abordagem contextual. In Espaço e Cultura, UERJ, RJ, n. 16, p. 47-56. jul/dez.

BINSZTOK, J., CAETANO, R.. (2009) Geografia e ideologia: Oliveira Vianna e Sérgio Buarque de Holanda. Geographia, América do Norte, 6, dez. . Disponível em: http://www.uff.br/geographia/ojs/index.php/geographia/article/view/141. Acesso em: 2 Jan. 2015.

BRESCIANI, M. S. M. (2007) O charme da ciência e a sedução da objetividade: Oliveira Vianna entre intérpretes do Brasil. 2 ed. São Paulo: Ed. UNESP.

COSTA, S. (2006) Dois Atlânticos: Teoria Social, Anti-racismo, Cosmopolitismo. Belo Horizonte: Editora UFMG.

CARVALHO, C. M. D. de. (1927) Geographia do Brasil, Tomo II. Geographia Regional. Rio de Janeiro: Francisco Alves.

CARVALHO, José Murilo de. (2000) Introdução. In: Introdução. In: Intérpretes do Brasil. Populações Meridionais do Brasil. Rio de Janeiro: Nova Aguilar, 2000, p.899-917.

. (1991) A Utopia de Oliveira Vianna. Estudos Históricos. Rio de Janeiro, n. 7, p. 8299.

GUIMARÃES, A. S. A. (2004) Preconceito de cor e racismo no Brasil, Revista de Antropologia, 47, 1 p. 9-43.

HOFBAUER, A. (2006) Uma história do branqueamento ou o negro em questão. São Paulo: Editora UNESP.

LACERDA, J. B. de. (1911) Sur le métis au Brésil. In: Premier Congrès Universel des Races: 26-29 juillet 1911. Paris: Devouge.

LIVINGSTONE, D N. (1992) The Geographical Tradition. London: Blackwell.

MACHADO, L. O. (2000) ideias fora do lugar: o desenvolvimento do pensamento geográfico no Brasil no início do século XX. In: Terra Brasilis, 2, acessado 14/11/13 em http://terrabrasilis.revues.org/298

(1995) Origens do pensamento geográfico no Brasil: meio tropical, espaços vazios e a idéia de ordem (1870-1930). In: CASTRO, Iná Elias; GOMES, P. C. Costa; CORRÊA, Roberto L.Geografia: conceitos e temas Rio de Janeiro: Bertrand, p. 309-353

MURARI, L. (2009) Natureza e cultura no Brasil (1870-1922). São Paulo: Ed. Alameda.

DAVID, Nally (2014). Race. MORRISSEY, J.; NALLY, D.; STROHMAYER, U.; WHELAN, Y. Key Concepts in Historical Geography. London: SAGE. p. 105-117. 
ORTIZ, R.. (2005) Cultura brasileira e identidade nacional. São Paulo: Brasiliense.

PEREIRA, S. N. (2008) Delgado de Carvalho e o ensino de Geografia Política. In: DOCUMENTOS para disseminação. Geografia e Geopolítica: a contribuição de Delgado de Carvalho e Therezinha de Castro. Rio de Janeiro: Instituto Brasileiro de Geografia - IBGE. p. 105-116.

(2005) Obsessões geográficas: viagens, conflitos e saberes no âmbito da Sociedade de Geografia do Rio de Janeiro. In: Revista da SBHC, Rio de Janeiro, v. 3, n.2. jul./dez., p. 112-124.

(2001) Tão perto, tão longe. In: Terra Brasilis, n 3. Acessado no dia 30/09/2013 em http://terrabrasilis.revues.org/325

PIVA, L. G. (2000) Oliveira Vianna: organização nacional. In: Ladrilhadores e semeadores. São Paulo: Ed. 34, p. 89-152.

REIS, J. C. (2006) Oliveira Vianna, intelectual das oligarquias rurais e do Estado Novo. In: As identidades do Brasil 2. Rio de Janeiro: Editora FGV, pg. 99-146

RICUPERO, B. Sete lições sobre as interpretações do Brasil. São Paulo: Alameda, 2011.

RODRÍGUEZ, R. V. Oliveira Vianna: o homem e sua obra. In: acessado 15/01/2015 em $<$ http://www.ensayistas.org/filosofos/brasil/vianna/introd.htm>.

SCHWARCZ, L. M. (1993) O espetáculo das raças. São Paulo: Companhia das Letras.

(1999) Questão racial e etnicidade. In: MICELI, Sergio (org.) O que ler nas Ciências Sociais (1970-1995). São Paulo: Editora Sumaré, ANPOCS; Brasília: CAPES. p. 267-325.

(org.). (2013) História do Brasil nação: A abertura para o mundo, 1889-1930. São Paulo: Objetiva.

SEGATO, R. L. (2007) La nación y sus otros: raza, etnicidad y diversidad religiosa en tiempos de políticas de la identidad. Buenos Aires: Prometeo Libros.

SEYFERTH, G. (2005) A colonização e a questão racial nos primórdios da República. In: SALGUEIRO, M. A. A. A República e a Questão do Negro no Brasil. Rio de Janeiro: Museu da República p 27- 46.

(1996) Construindo a nação: Hierarquias raciais e o papel do racismo na política de imigração e colonização. In: MAIO, M. C. e SANTOS, R. V. (org.). Raça, Ciência e Sociedade. Rio de Janeiro: Editora Fiocruz/CCBB, p. 41-58.

SKIDMORE, T. E. (1976) Preto no branco: raça e nacionalidade no pensamento brasileiro. 2. ed. Rio de Janeiro: Paz e Terra. 
SOUSA NETO, M. F. de. (2001) Geografia nos trópicos: história dos náufragos de uma jangada de pedras?. In: Terra Livre, № 17, São Paulo: AGB, p. 119-137.

VIANNA, O. (1933[1923]) Evolução do povo brasileiro. Rio de Janeiro: Companhia Ed. Nacional.

Federal.

(1999[1949]) Instituições políticas brasileiras. Brasília: Conselho editorial do Senado . (1959[1932]) Raça e assimilação. 4 ed. Rio de Janeiro: José Olympio Editora.

. (1933) Populações meridionais do Brasil. Rio de Janeiro: Companhia Ed. Nacional.

\section{NOTAS DE AUTOR}

\section{CONTRIBUIÇÃO DE AUTORIA}

Diogo Marçal Cirqueira - Concepção. Coleta de dados, Análise de dados, Elaboração do manuscrito, revisão e aprovação da versão final do trabalho.

\section{FINANCIAMENTO}

Coordenação de Aperfeiçoamento de Pessoal de Nível Superior - CAPES

\section{CONSENTIMENTO DE USO DE IMAGEM}

Não se aplica.

\section{APROVAÇÃO DE COMITÊ DE ÉTICA EM PESQUISA}

Não se aplica.

\section{CONFLITO DE INTERESSES}

Não se aplica.

\section{LICENÇA DE USO}

Este artigo está licenciado sob a Licença Creative Commons CC-BY. Com essa licença você pode compartilhar, adaptar, criar para qualquer fim, desde que atribua a autoria da obra.

\section{HISTÓRICO}

Recebido em: 24-07-2018

Aprovado em: 18-03-2019 